\title{
Analysis of Effect of Capital Structure, Corporate Social Responsibility to Profitability and Implications on Company Value (Case Study on Property and Real Estate Companies Listed on Indonesia Stock Exchange)
}

\author{
Armalia Reny ${ }^{1}$, Andi Surya ${ }^{2}$, Yudhinanto $\mathrm{CN}^{3}$ \\ \{armalia.reni@umitra.ac.id ${ }^{1}$, andisangsurya@umitra.ac.id ${ }^{2}$, yudhi@umitra.ac.id ${ }^{3}$ \} \\ ${ }^{1,2,3}$ Lecturer of Economic Faculty Universitas Mitra Indonesia, Lampung, Indonesia
}

\begin{abstract}
The aim of the study is to analyze the corporate social responsibility effect of capital structure on profitability and its involvement on company value. The data is obtained from property companies and real estate listed on the 2011-2015 period in the Indonesia Stock Exchange (IDX). The method of this study is using path analysis. The result shows that partially element of corporate social responsibility and capital structure have significant and constructive effect on profitability. The element of profitability and capital structure have a significant and constructive effect on firm value. On the other side, responsibility of corporate social element has a negative and destructive effect on company value. The result shows that profitability can influence the interaction between firm value and capital structure as well as the interaction between company social responsibility and corporate value. Both of these interactions show a positive and significant influence on company value.
\end{abstract}

Keyword: Corporate Social Responsibility, Firm Value, Capital Structure, Profitability.

\section{Introduction}

The company is founded with various aims and objectives. Some corporate goals maximize corporate value, maximize profits, create prosperity for stakeholders, create a corporate image and increase social responsibility[1]. In the process, one of the influential to achieve the goals of a company is a financial manager. According to Darsono (2009) financial manager is the person who manages the finances of an organization[2]. According to Martono \& Harjito (2008) describes financial management as an activity to obtain funds, use funds and manage assets efficiently requires several goals or targets[3]. As a normative goal (should) the purpose of financial management related to the decision in the field of finance financial manager must also consider the level of profitability or ability of the company in generating profits.

Profitability affects investors' perceptions of the company's future growth prospects and will increase investor confidence to invest funds. The need for capital is very important in building and ensuring the continuity of the company in addition to other supporting factors. Capital is needed for every company, especially if the company will do the expansion. Therefore, the company must determine how much capital is needed to meet or finance its business. The need for such capital can be met from various sources and have different types. 
Capital consists of equity (own capital) and debt (debt), comparison of long-term debt and own capital in the financial structure of company is called capital structure[4].

But in recent years, business circles, especially in developed countries, are increasingly aware that the continuity of their business will not last long if only focus on profit. In the long run, companies will get into trouble if they do not improve the quality of social, economic, cultural, and environmental management [5]. Rachbini (1997) in Hamidi (2014), the growing investment trend in society today is investing money in land or property that has resulted in the property sector and real estate industry growing rapidly and more and more companies are taking part in the utilization of this opportunity[6]. Land prices lean to increase, provided land is constant while demand will rise as the population also rising as the cause, besides price of land is stilted, meaning the price determinant is not the market but the people who control the land. It should be if the developer companies get big profits from the price increase property, and with the profits gained, the developer can improve its financial performance so as to increase the value of the stock, as the increase in stock prices can rise the company value.

The capitalization of the real estate and property market in the course of period 20112015 has increased significantly from Rp 126,595 to Rp 290,406. It proves that the sector of real estate and property from year to year is one of the sectors that are in great demand by investors.

Corporates in the sector real estate and property require funds to specify the capital structure of the corporate. In addition, the sector real estate and property are engaged in the construction of houses, buildings, apartments and other buildings that will reduce the green open space, so that companies engaged in this sector should be more concerned with corporate social responsibility activities.

Therefore, this study is conducted to recognize 1) How the effect of capital structure, company social responsibility simultaneously or partially to profitability. 2) How the influence of corporate social responsibility of capital structure, and profitability simultaneously or partially on the value of the company. 3) How the influence of capital structure on profitability and its implications on corporate value. 4) How corporate social responsibility impacts profitability and its involvement on firm value.

\section{Literature Review}

The foundation of this theory describes theories that support the hypothesis as well as useful in the analysis of research results. Theoretical basis contains the exposure of theories and arguments are prepared as a guide in solving research problems and formulation of hypotheses.

\subsection{Capital Structure}

According to Weston and Copeland in that. So it can be understood that the capital structure is an explanation of the form of a financial proportion in the corporate that is between capital owned by origin from long-term liabilities and equity of shareholder (which is the source of financing a company). The need for funds to strengthen the capital structure of an enterprise can be sourced internally and externally, provided that the required funding source is sourced from places considered safe (safety position) and if used as a value of thrust in strengthening the structure of the capital financial company.

The capital structure policy involves a change among return and risk:

1. The use of more debt will increase the risk borne by shareholders, such as insolvency risk, interest rate hike and financial distress. 
2. The use of larger debt will usually lead to higher return on equity expectations.

\subsection{Corporate Social Responsibility (CSR)}

Corporate social responsibility is a responsibility for a corporate to communicate all operational and non-operational activities of the company and its consequences to the social and the environment. CSR is closely related to the process of sustainable development, meaning all operational and non-operational activities of the company are not only to meet and benefit from the financial aspect but should get more attraction to the environmental social elements and surrounding[7].

In this regard, John Elkington's is based on the notion of CSR as described above, classifying CSR into three aspects, better known as "Triple Bottom Line (3BL)." These three aspects include prosperity or economic wealth, (environmental level), and social justice. It also emphasizes that a company that wishes to apply sustainable development concept should get more attention to Triple $\mathrm{P}$ that is Planet, People, and Profit. In case linked between 3BL with "Triple P", it can be determined that "People" as a social aspect, "Planet" as a form of environmental aspect, and "Profit" as a form of economic aspect.[8].

\subsection{Profitability}

Profitability is the power of a corporate to generate profit or profit for one year expressed in the ratio of operating profit to sales of income statement data end of the year. Profitability ratios also show a combination of the operating results[9].

The purpose of using profitability ratios for the company as well as for outsider[10], namely:

1. To profit earned by in.

2. Progress of Profits.

3. Amount.

4. All corporate funds used either own.

5. All corporate funds used either own capital.

6. And other goals.

Obtained:

1. Knowing profit earned by in one.

2. Knowing the position.

3. Knowing of profit over.

4. Knowing the amount of.

5. Knowing of all corporate funds used either loan capital or own capital.

Value of can be considered a "ball cake". The purpose of the manager is "ball cake" decisions (decisions well the "ball cake" is cut. affects the of "then capital structure's is influenced. value company is the coupled and.

\subsection{Interconnected Linkages}

1. Effect of Capital Structure on Profitability

Brigham and Houston (2006) debate that the trade-off theory has implications managers will think in the framework of the trade-off between saving the tax and difficulties offinancial in deciding the capital structure[12]. Corporates with higher grade of profitability will sure try to decrease taxes by rising the ratio of financial obilgation, so the additional financial obilgation will reduce taxes.

2. Influence of Corporate Social Responsibility to Profitability 
Based to Sari and Suaryana (2013), stated that the establishment of Corporate Social Responsibility (CSR), the consumer will give a positive reaction to the products produced by the company and increase consumer loyalty to a product. Consumer loyalty is what will increase product sales, which impact on increasing corporate profits[13].

3. Effect of Capital Structure on Corporate Value

The matter of capital structure is a necessary issue for any corporate because the quality of the capital structure of corporate will have an effect on its positioning financial. In the trade-off theory that when the capital structure's position is above the target of optimal capital structure, then each forest increase can decrease company grade and vice versa.

4. Influence of Corporate Social Responsibility to Corporate Value

In the theory of legitimacy and stakeholder theory that the company can not break away with the surrounding social and companies have to manage the authenticity of stakeholders and occupy it in the framework of decision making and policies, so as to help the goals of corporate aims. Nurlela and Islahuddin (2008) explained that the priority goal of the company is to rise the grade of the company. The grade of the company will be guaranteed to grow sustainably if the company takes into account the economical dimension, social dimension, and environmental dimension because sustainability is a balance among economic interests, environment, and society. [14].

5. Effect of Profitability on Corporate Value

Brigham and Houston (2004) stated that if management wants to maximize the value of a company, it must take advantage of the strengths of the company and fix its weaknesses[15]. According to Dewi and Wirajaya (2013), states that high profitability reflects the company's ability to generate profits which are high for shareholders. The greater the profit earned the greater the company's ability to pay dividends, and this affects the increase in corporate value[16].

6. Effect of Capital Structure on Profitability and Its Implication on Corporate Value According to Hamidy, et al (2014), states that the increase in debt will increase the net income of companies that led to increased profitability[6]. High profitability will be a good marker for shareholders or prospective shareholders, because of profitability as the ratio of return on funds invested by shareholders. The relationship between shareholders and prospective shareholders will increase demand for stocks from the company so that stock prices will rise, the rise in stock prices encourages the value of companies to rise.

7. Effect of Corporate Social Responsibility on Profitability and Its Implication on Corporate Value

According to Agustine (2014), stated that the disclosure of Corporate Social Responsibility (CSR) will be able to strengthen brand positioning, increasing corporate image, and market share[17]. With increasing market share will be able to increase sales and increase corporate profits, so the company's profitability ratio will also increase. With the increase in profitability as one measure of investors in investing shares will have an impact on increasing the value of thecompany.

In this research to know the relation between a variable of capital structure, corporate social responsibility towards profitability and its implication to company value in property and real estate company listed in Indonesia Stock Exchange (BEI) period 2011-2015, so that can be formed a model of thought relationship as following (Figure 1) : 


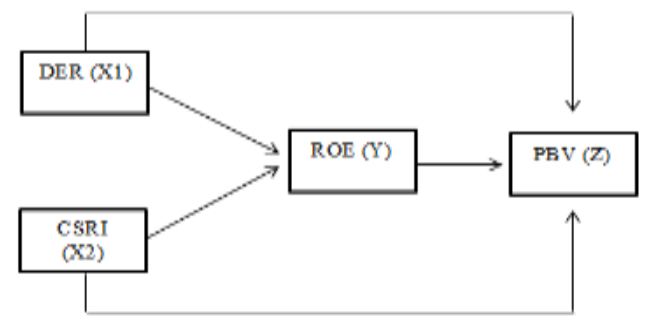

Fig. 1. Relationship Model of Thought

\section{Research Methodology}

Data Processing is property and real estate companies listed in Indonesia Stock Exchange (IDX) period 2011-2015. Data used in this study is secondary data, data sourced from Indonesia Stock Exchange (IDX), www.idx.co.id, and other sources that support this research.Data processing of this research is done by using program of Microsoft Excel and Lisrel 8.8. Teknik sampling is by purposive sampling. Purposive Sampling is the technique of determining the sample with certain considerations and the sample members are adjusted to the purpose of research[18]. Sample this study obtained from IDX factbook from IDX during the 2011-2015 period, with sample criterion determined by the researcher. Based on sampling technique obtained as many as 125 companies used as sample research.

The analytical method used to analyze the influence of capital structure variable, corporate social responsibility towards profitability and its implication on company value by using path analysis method. Path analysis test exogenous variable and endogen variable measure direct and indirect relationship[19]. Hair et.al (1998) in Ghozali (2008) proposed a modeling and equation analysis to 7 (seven) steps[19]:

Step 1: Model-Based Theory Development

The structural equation model is based on causality, where the change of a variable is assumed to result in other theoretical variables change.

Steps 2 and 3: Prepare Path Charts and Structural Equations

The next step is to establish causality relationships with path diagrams and structure their structural equations.

Step 4: Select the Matrix Input Type and Proposed Estimates

Using input data in the form of variance/covariance matrix or correlation matrix.

Step 5: Assess Identification of Structural Models

During the process of estimation with the program in the computer, it is often found that the results are ilogical or pointless and it is related to the problem of structural model identification. The way to see whether there is a problem in identification is to look at the results of estimation which contain: (1) the existence of a huge error value in standard for a coefficient or more than one coefficients. (2) the inability of the program to invert the matrix of information, the impossible value of estimation, for example, a negative variance error, (4) the value of high correlation $(>0.90)$ between the measureable coefficients. 
Step 6: Assess the Goodness-of-Fit Criteria

One of the objectives of Path Analysis is to determine whether the model is plausible (reasonable) or fit. A research model is said to be good, if it has a good fit model as well.

Step 7: Interpretation and Modification of the Model

When the declared model has been accepted, the researcher may contemplate to modify the model to correct theoretical or goodness-of-fit explanations. Modifications of the initial model should be done after consideration. If the model has been modified, the model has to be crossvalidated with separated data before the modified model is able to be accepted.

\subsection{Variable Operationalization}

This study used endogenous variables and exogenous variables:

1. Operational Endogenous Variables Research

a. Profitability (Variable Control)

Is the ratio to assess the ability of companies in the search for profit, the ratio used to measure profitability is the result of return or return on equity (ROE). The formula for calculating return on equity[20]:

$$
R O E=\frac{\text { Earing After Interest and Tax }}{\text { Equity }}
$$

b. Company Value (Variable Bound)

In the value of the market, because the market value can give maximum prosperity for the shareholder if the company's stock price increases, the company's grade is measured by Price to Book Value (PBV). Price to book value calculation formula[12]:

$$
P B V=\frac{\text { Stock price }}{\text { Value of Share Book }}
$$

2. Operational Exogenous Variables Research

a. Capital Structure (Independent Variables)

It is the technic to compare in determining the company's spending needs, whether by the use debt, equity or by offering shares. To measure the ratio of the structure of the capital, Debt to Equity Ratio (DER) is used. The formula for calculating debt to equity ratio[21]:

$$
D E R=\frac{\text { Total Debt }}{\text { Total Equity }}
$$

b. Corporate Social Responsibility (Independent Variables)

It is an obligation for the company to communicate all operational and nonoperational activities of the company and its consequences to the social and the environment[7].

Corporate Social Responsibility as measured by Corporate Social Responsibility Index (CSRI) and using the Global Reporting Initiative (GRI) indicator table. To decide the level of the unveiling of social information using the score is as follows: Score 0: If the corporate does not reveal the items on the questionnaire. Score 1: If the corporate discloses the items on the question. The measurement is then performed according to the disclosure index of each company which is calculated through the sum of the items the company discloses by the sum of all possible items disclosed.

Calculation formula corporate social responsibility index: 


$$
\begin{aligned}
& \text { CSRI }=\frac{n}{k} \\
& \text { Information: CSRI = corporate disclosure index } \\
& \mathrm{n} \quad=\text { number of disclosure items met } \\
& \mathrm{k}=\quad=\text { the number of all items that may be fulfilled. }
\end{aligned}
$$

\section{Results and Discussion}

Analysis of this pathway analyzes the influence of the structure of the capital, corporate social responsibility towards profitability and its implications on the value of the company. From Lisrel calculation 8.8 it can be described the path diagram as follows

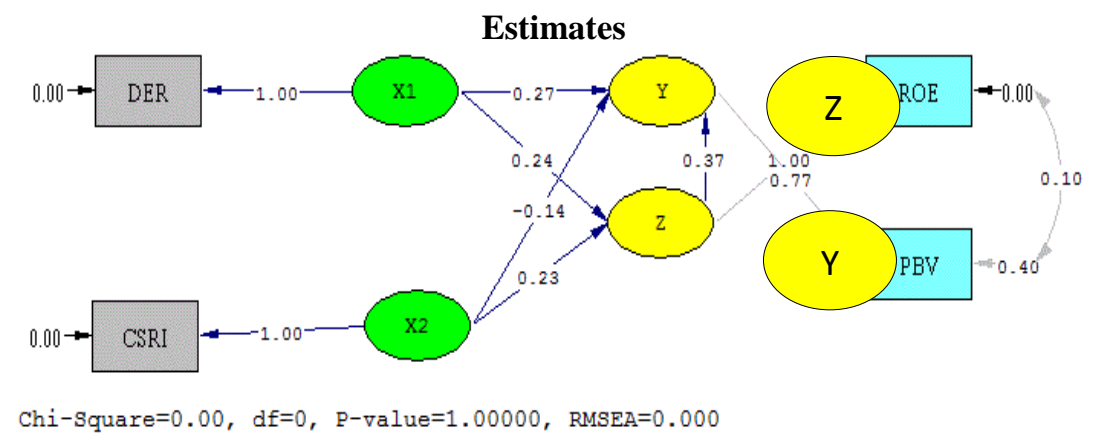

Figure 1: Line Chart with Calculation Results (Results Output Lisrel 8.8)

\section{T Test}

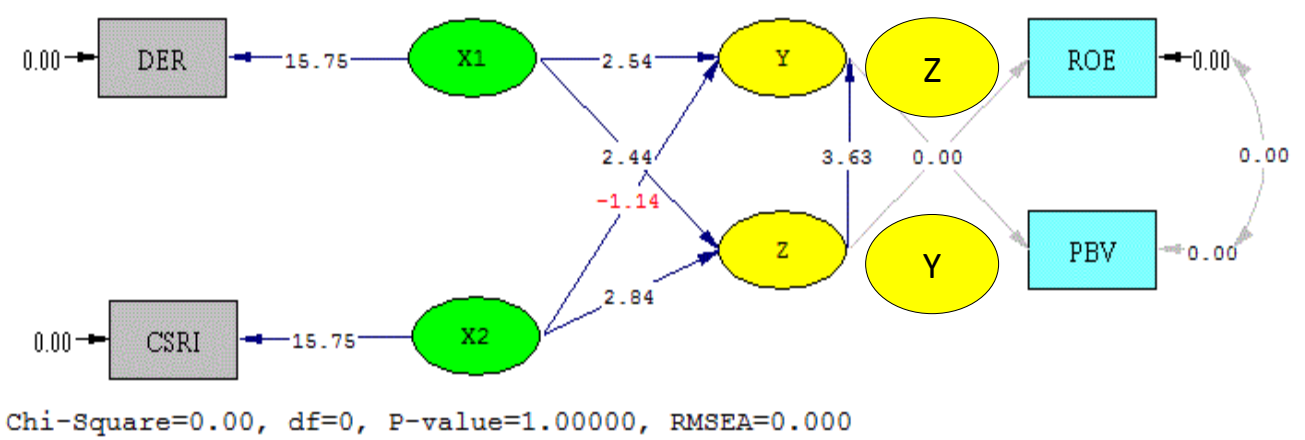

Figu. 1. Line Chart with Calculation (Results Output Lisrel 8.8)

\subsection{Correlation Analysis}

Correlation between capital structure, corporate social responsibility, profitability, a corporate value can be seen in the table as follows: 
Table 3: Correlation Results

\begin{tabular}{|l|r|r|r|r|}
\hline & ROE & PBV & DER & CSRI \\
\hline ROE & 1.00 & & & \\
\hline PBV & 0.42 & 1.00 & & \\
\hline DER & 0.70 & 0.26 & 1.00 & \\
\hline CSRI & 0.32 & 0.06 & 0.37 & 1.00 \\
\hline
\end{tabular}

Source: Results Output Lisrel 8.8

To interpret the number used the following criteria :

$0-0,25 \quad:$ The correlation is very weak (considered absent)

$>0,25-0,5 \quad:$ The correlation is strong enough

$>0,5-0,75 \quad:$ The correlation is strong

$>0,75-1 \quad:$ The correlation is very strong

1. Correlation between capital structure (DER) to corporate social responsibility (CSRI) that is equal to 0,37 has intention correlation between capital structure (DER) to corporate social responsibility (CSRI) enough strong.

2. Correlation between capital structure (DER) to profitability (ROE) that is equal to 0.70. The correlation of 0.70 has the intention of a strong relationship.

3. Correlation between corporate social responsibility (CSRI) to profitability (ROE) that is equal to 0.32 . The correlation of 0.32 has the intention of a strong enough relationship.

4. The correlation between profitability (ROE) to firm value (PBV) is 0.42 . The correlation of 0.42 has the intention of a strong enough relationship.

5. Correlation between capital structure (DER) to company value (PBV) that is equal to 0,26 . The correlation of 0.26 has the intention of a strong enough relationship.

6. Correlation between corporate social responsibility (CSRI) to company value (PBV) that is equal to 0,06 . A correlation of 0.06 has the intention of a very weak relationship or no correlation.

\subsection{Model Conformity Test (Goodness of Fit)}

To determine whether the model is appropriate or not, then the fitness tested the model (goodness of fit) as follows:In the above table. The results of processing for the test of goodness of fit showed in chi-square test obtained conclusion p-value $1.0>0.05$ so Ho is accepted and $\mathrm{Ha}$ is rejected which means the model produced goodness of fit that has shown that the model is very good. In addition, it provides an alternative use of other goodness of fit indicators. The RMSEA criterion produces a value of $0.000 \leq 0.08$ which means that the result of the model is the goodness of fit.

The use of another goodness of fit criteria that is GFI, NFI and CFI yield value> 0.9 which means that the resulting model has the goodness of fit. Because the conclusion of several indicators resulted in the conclusion of the goodness of fit model hence the testing of hypothesis theory can be done.

\subsection{Path Analysis of Capital Structure, Corporate Social Responsibility to Profitability.}

Table 4: Influence between Capital Structure (DER), Corporate Social Responsibility

(CSRI) toProfitabilitas (ROE)

\begin{tabular}{|c|c|c|c|c|c|c|}
\hline Simultan & Path & Estimasi (Direct & S.E. & $\mid$ t-hit $\mid>$ & R-square & Conclusion \\
\hline
\end{tabular}




\begin{tabular}{|c|c|c|c|c|c|c|}
\hline & & Effects $)$ & & 1.96 & & \\
\hline \multirow{2}{*}{$\mathrm{Y} \leftarrow \mathrm{X} 1+\mathrm{X} 2$} & $\mathrm{Y} \leftarrow \mathrm{X} 1$ & 0.24 & 0.098 & 2.44 & \multirow{2}{*}{0.15} & Signifikan \\
\cline { 2 - 5 } & $\mathrm{Y} \leftarrow \mathrm{X} 2$ & 0.23 & 0.082 & 2.84 & \multirow{2}{*}{ Signifikan } \\
\hline
\end{tabular}

Source: Results Output Lisrel 8.8

To see the effect of capital structure (DER) and corporate social responsibility (CSRI) simultaneously to profitability (ROE), we can see the result of calculation of table 4.9 especially R Square. The magnitude of R Square $\left(r^{2}\right)$ is equal to 0.15 . This figure is used to see the influence of capital structure variable (DER) and corporate social responsibility (CSRI) simultaneously to profitability (ROE) by calculating the coefficient of determination (KD) by using the following formula:

This figure means that the effect of capital structure variable (DER) and corporate social responsibility (CSRI) on profitability (ROE) simultaneously is $15 \%$. While the rest equal to $85 \%(100 \%-15 \%)$ influenced by other factors. In different explanation, the variability of satisfaction that is possible to be explained by using the variable of capital structure (DER) and corporate social responsibility (CSRI) is $15 \%$, while the effect caused by other variables outside of this model is $85 \%$.

To see the effect of capital structure (DER) and corporate social responsibility (CSRI) partially to profitability (ROE), use the estimation column in table 4.9, while to see the significance used column $t$ arithmetic.

Influence between capital structure (DER) to profitability (ROE) estimation result obtained equal to 0,24 which means a higher capital structure (DER) will be greater profitability (ROE) directly and vice versa. These results indicate that the proposed hypothesis theory with a statistical value of 2.44> t-table 1.96 which means Ho is rejected so it is to be concluded that there is a positive and the influence is significant.

The effect of corporate social responsibility (CSRI) on profitability (ROE) estimated calculation is 0.23 which means that the higher corporate social responsibility (CSRI) will be greater profitability (ROE) directly and vice versa. These results indicate that the proposed hypothesis theory with a statistical value of $2.84>$ t-table 1.96 which means Ho is rejected so it can be concluded that there is a positive and the influence is apparent.

\subsection{Analysis of Influence Line of Capital Structure, Corporate Social Responsibility, and Profitability to Company Value}

Table 5: Influence between Capital Structure (DER), Corporate Social Responsibility (CSRI) andProfitabilitas (ROE) of Corporate Value (PBV)

\begin{tabular}{|c|c|c|c|c|c|c|}
\hline \multirow{2}{*}{ Simultan } & Path & $\begin{array}{c}\text { Estimasi (Direct } \\
\text { Effects) }\end{array}$ & S.E. & $\begin{array}{c}\mid \text { t-hit } \mid> \\
1.96\end{array}$ & $\begin{array}{c}\text { R- } \\
\text { square }\end{array}$ & Conclusion \\
\hline \multirow{3}{*}{$\mathrm{Z} \leftarrow \mathrm{Y}+\mathrm{X} 1+\mathrm{X} 2$} & $\mathrm{Z} \leftarrow \mathrm{X} 1$ & 0.27 & 0.100 & 2.54 & \multirow{2}{*}{0.23} & significant \\
\cline { 2 - 5 } \cline { 3 - 5 } & $\mathrm{Z} \leftarrow \mathrm{X} 2$ & -0.14 & 0.120 & 1.14 & Not significant \\
\cline { 2 - 5 } & $\mathrm{Z} \leftarrow \mathrm{Y}$ & 0.37 & 0.100 & 3.63 & & significant \\
\hline
\end{tabular}

Source: Results Output Lisrel 8.8

To see the effect of capital structure (DER), corporate social responsibility (CSRI) and profitability (ROE) simultaneously to company value (PBV), we can see the result of table count 4.10 especially $\mathrm{R}$ Square number.

The magnitude of $R$ Square $\left(r^{\wedge} 2\right)$ is 0.23 . This figure is used to see the effect of capital structure variable (DER), corporate social responsibility (CSRI) and profitability (ROE) 
simultaneously is $23 \%(0,23 \times 100 \%)$, while the rest equal to $77 \%(100 \%-23 \%)$ influenced by other factors. In other words, the variability that can be explained by using capital structure (DER), corporate social responsibility (CSRI) and profitability (ROE) on company value (PBV) is $23 \%$ and $77 \%$ is caused by other variables outside the scope of this model.

To see the influence of capital structure (DER), corporate social responsibility (CSRI) and profitability (ROE) to the value of the company (PBV) partially, use the estimation column in table 4.10, while to see significant use column $t$ arithmetic.

Influence between capital structure (DER) to company value (PBV) estimation result obtained equal to 0,27 which means a higher capital structure (DER) will be bigger value company (PBV) directly and vice versa. These results indicate that the proposed hypothesis with a statistical value of 2.54> t-table 1.96 which means Ho is rejected so it can be concluded that there is positive and significant influence.

The influence of corporate social responsibility (CSRI) on corporate value (PBV) estimation result is obtained at -0.14 , which means that the higher corporate social responsibility (CSRI) will be smaller than the company value (PBV) directly and vice versa. These results indicate that the proposed hypothesis theory with a statistical value of $1.14<\mathrm{t}$ table 1.96 which means Ho accepted so it can be concluded that negative and not significant.

The effect of profitability (ROE) on firm value (PBV) of estimate processing result is 0.37, which means that higher profitability (ROE) will be a greater value of a company (PBV) directly and vice versa. These results indicate that the proposed hypothesis theory with a statistical value of 3.63> t-table 1.96 which means Ho is rejected so it can be summarized that there is positive and apparent influence.

Table 6: Influence between Capital Structure (DER), Corporate Social Responsibility (CSRI) of Corporate Value (PBV) with Profitability as a VariableIntervening

\begin{tabular}{|c|c|c|c|c|c|c|}
\hline \multirow{2}{*}{ Simultan } & Path & $\begin{array}{c}\text { Estimate (Indirect } \\
\text { Effects) }\end{array}$ & S.E. & $\begin{array}{c}\mid \text { t-hit } \mid> \\
1.96\end{array}$ & $\begin{array}{c}\text { R- } \\
\text { square }\end{array}$ & Conclusion \\
\hline \multirow{2}{*}{-} & $\mathrm{Z} \leftarrow \mathrm{Y} \leftarrow \mathrm{X} 1$ & 0.09 & 0.040 & 2.11 & & Signifikan \\
\cline { 2 - 5 } \cline { 3 - 5 } & $\mathrm{Z} \leftarrow \mathrm{Y} \leftarrow \mathrm{X} 2$ & 0.09 & 0.040 & 2.20 & & Signifikan \\
\hline
\end{tabular}

Source: Results Output Lisrel 8.8

The calculation result of the estimation is 0,09 . These results indicate that the proposed hypothesis with a statistical value of 2.11>t-table 1.96 which means Ho is rejected so it can be concluded that there is an indirect influence between the capital structure (DER) on the firm value (PBV) in a positive and significant or variable profitability (ROE) able to mediate the variable of capital structure (DER) to firm value (PBV) positively and significantly.

Then the calculation result of estimation is obtained equal to 0,09 . These results indicate that the proposed hypothesis with a statistical value of $2.20>$ t-table 1.96 which means Ho is rejected so it can be concluded that there is an indirect influence between corporate social responsibility (CSRI) to the value of the company (PBV) in a positive and significant or variable profitability (ROE) are able to mediate the corporate social responsibility (CSRI) variable on firm value (PBV) positively and significantly. 


\section{Conclusions and Recommendations}

The effect of capital structure, corporate social responsibility on profitability and its implications on firm value. Based on the test results and discussion that have been done in the previous section, the conclusions might be stated as follows:

1. The capital structure represented by the proxy of debt to equity ratio (DER) and corporate social responsibility represented by the proxy of corporate social responsibility index (CSRI) simultaneously affect the profitability represented by the proxy of return on equity ratio (ROE) of 0.15 or $15 \%$ and partially DER and CSRI have a positive and significant effect on ROE.

2. The structure of the capital represented by the proxy of debt to equity ratio (DER), corporate social responsibility represented by the proxy of corporate social responsibility index (CSRI) and profitability represented by the proxy of return on equity ratio (ROE) simultaneously affect the grade of the company represented by the proxy price to book value (PBV) $\mathrm{S}$ with $\mathrm{R}$ square level of 0.23 or $23 \%$. Partially DER and ROE have a positive and apparent effect on PBV, whereas CSRI has a negative and insignificant effect on PBV.

3. The capital structure represented by the proxy of debt to equity ratio (DER) has a positive and significant impact on the concept of profitability represented by the proxy of return on equity ratio (ROE) and its implications on the value of the company represented by the proxy price o book value (PBV) rejected and Ha accepted. In other words, it can be said that profitability has the ability to become a mediator between capital structure and firm value.

4. Corporate social responsibility represented by the proxy of corporate social responsibility index (CSRI) has a positive and apparent effect on the profitability represented by the proxy of return on equity ratio (ROE) and its implication to the grade of the company represented by proxy price o book value (PBV) with Ho thus rejected and Ha accepted. In other words, profitability can mediate between corporate social responsibility and corporate value.

Seeing on the conclusions that have been described, the authors put forward some suggestions that may be useful, namely:

1. Using more accurate data with the greater amount of data and with longer time spans. Longer use of data allows better research results.

2. Using methods and tools more complete and accurate test so that obtained a more valid conclusion.

3. Corporate social responsibility disclosure items should always be updated according to the conditions in the community.

\section{References}

[1] Kasmir, Pengantar Manajemen Keuangan. Jakarta: Kencana Prenada Media Group, 2010.

[2] Darsono, Akutansi Manajemen, 3rd ed. Jakarta: Mitra Wacana Media, 2009.

[3] Martono and A. Harjito, Manajemen Keuangan. Yogyakarta: Ekonesia, 2008.

[4] S. Husnan, Dasar-Dasar Manajemen Keuangan, 4th ed. Yogyakarta: UPP SMP YKPN, 2004. 
[5] M. Dwi Restuti and C. Nathaniel, "Pengaruh Pengungkapan Corporate Social Responsibility Terhadap Earning Response Coefficient," J. Din. Manaj., vol. 3, no. 1, pp. 40-48, Mar. 2012.

[6] R. R. Hamidy, I. G. B. Wiksuana, and L. G. S. Artini, "Pengaruh struktur modal terhadap nilai perusahaan dengan profitabilitas sebagai variabel intervening pada perusahaan properti dan real estate di bursa efek Indonesia," E-Jurnal Ekon. dan Bisnis Univ. Udayana, vol. 4, no. 10, pp. 665-682, 2014.

[7] R. H. Wakidi and H. S. Siregar, "Pengaruh Sisi Internal dan Eksternal Perusahaan terhadap Pengungkapan Tanggung Jawab Sosial pada Perusahaan Manufaktur yang Terdaftar di BEI," J. Ekon., vol. 14, no. 4, 2011.

[8] B. Azheri, Corporate Social Responsibilty dari Voluntary Menjadi Mandatory. Jakarta: PT. Raja Grafindo Persada, 2012.

[9] E. F. Brigham and J. F. Houston, Dasar-dasar manajemen keuangan, 11th ed. Jakarta: Salemba Empat, 2010.

[10] Kasmir, Analisis Laporan Keuangan. Jakarta: PT Raja Grafindo Persada, 2015.

[11] Y. J. Christiawan and J. Tarigan, "Kepemilikan Manajerial: Kebijakan Hutang, Kinerja dan Nilai Perusahaan," J. Akunt. dan Keuang., vol. 9, no. 1, pp. 1-8, 2007.

[12] E. F. Brigham and J. F. Houston, Fundamental of Financial Management, 10th ed. Jakarta: Salemba Empat, 2006.

[13] N. L. K. M. Sari and G. N. A. Suaryana, "Pengaruh Pengungkapan CSR Terhadap Kinerja Keuangan dengan Kepemilikan Asing Sebagai Variabel Moderator," E-Jurnal Akunt., pp. 248-257, 2013.

[14] R. I. Nurlela, "Pengaruh Corporate Social Responsibility terhadap Nilai Perusahaan dengan Prosentase Kepemilikan sebagai Variabel Moderating," Simp. Nas. Akunt. XI, 2008.

[15] E. F. Brigham and J. F. Houston, Financial Management, 10th ed. Jakarta: Salemba Empat, 2004.

[16] A. S. M. Dewi and A. Wirajaya, "Pengaruh Struktur Modal, Profitabilitas dan Ukuran Perusahaan pada Nilai Perusahaan," E-jurnal Akunt., vol. 4, no. 2, pp. 358-372, 2013.

[17] I. Agustine, "Pengaruh Corporate Social Responsibility Terhadap Nilai Perusahaan," $J$. Finesta, vol. 2, no. 1, pp. 42-47, 2014.

[18] Sugiyono, Metode Penelitian Kuantitatif Kualitatif dan $R \& D$. Bandung: Alfabeta, 2011.

[19] I. Ghozali, Model Persamaan Struktural Konsep dan Aplikasi dengan Program Amos 16.0. Semarang: Badan penerbit UNDIP, 2008.

[20] Cashmere, Financial Statement Analysis. Jakarta: Raja Grafindo, 2012.

[21] A. Rodoni and H. Ali, Manajemen Keuangan, 1st ed. Jakarta: Mitra Wacana Media, 2010 . 